\title{
Anti-inflammatory effects of Sanguisorbae Radix water extract on the suppression of mast cell degranulation and STAT-1/Jak-2 activation in BMMCs and $\mathrm{HaCaT}$ keratinocytes
}

\author{
Ju-Hye Yang(D, Jae-Myung Yoo, Won-Kyung Cho* and Jin Yeul Ma*
}

\begin{abstract}
Background: Sanguisorbae Radix (SR) is a well-known herbal medicine used to treat inflammatory disease and skin burns in Asia. In addition, it is used to treat many types of allergic skin diseases, including urticaria, eczema, and allergic dermatitis. SR has been reported to exhibit anti-wrinkle, anti-oxidant, and anti-contact dermatitis bioactivities.

Methods: In this study, we investigated the mechanism underlying the anti-inflammatory effects of SR water extract (WSR) using human keratinocyte (HaCaT) cells and BALB/C mouse bone marrow-derived mast cells (BMMCs). Viability assays were used to evaluate non-cytotoxic concentrations of WSR in both BMMCs and HaCaT cells. To investigate the effect of WSR treatment on the degranulation of IgE/Ag-activated BMMCs, we measured the release of $\beta$-hexosaminidase $(\beta$-HEX). We determined the production of pro-inflammatory chemokines including thymus and activation regulated chemokine (TARC; CCL17), regulated on activation, normal T-cell expressed and secreted (RANTES; CCL5), macrophage-derived chemokine (MDC; CCL22), and interleukin 8 (IL-8; CXCL8) in stimulated human keratinocytes. The ability of WSR to reduce the expression of pro-inflammatory marker proteins was evaluated by Western blotting in $\mathrm{HaCaT}$ cells stimulated with tumor necrosis factor (TNF)-a/interferon (IFN)- $\gamma$.
\end{abstract}

Result: WSR inhibited IgE/Ag-activated mast cell degranulation in BMMCs. Treatment with various concentrations of WSR decreased $\beta$-HEX release in a dose-dependent manner with an $I C_{50}$ of $27.5 \mu \mathrm{g} / \mathrm{mL}$. In keratinocytes, WSR suppressed TNF-a/IFN- $\gamma$-induced chemokine production and pro-inflammatory molecules via a blockade STAT-1, Jak-2, p38, and JNK activation.

Conclusions: This results demonstrate that WSR inhibits degranulation of IgE/Ag-activated mast cells and inhibits the production of pro-inflammatory chemokines by suppressing the phosphorylation of p38 and JNK in HaCaT cells.

Keywords: Sanguisorbae Radix, Mast cells, Degranulation, Keratinocytes, Chemokines

Abbreviations: AD, Atopic dermatitis; BMMCs, Mouse bone marrow-derived mast cells; FceRl, High-affinity immunoglobulin E receptor; IFN-y, Interferon- $;$; IL-8, Interleukin 8; MDC, Macrophage-derived chemokine; RANTES, Regulated on activation normal T-cell expressed and secreted; TARC, Thymus and activation regulated chemokine; TNF-a, Tumor necrosis factor-a; WSR, Water extract of Sanguisorbae Radix; $\beta$-HEX, $\beta$-hexosaminidase

* Correspondence: wkcho@kiom.re.kr; jyma@kiom.re.kr

Korean Medicine (KM) Application Center, Korea Institute of Oriental

Medicine, 70 Cheomdan-roDong-gu, Daegu 41062, Republic of Korea 


\section{Background}

Atopic dermatitis (AD) is an obstinate chronic inflammatory skin disease that progresses through the activation of inflammatory cells such as $\mathrm{T}$ cells, monocytes, macrophages, eosinophils, keratinocytes, and mast cells. AD causes epidermal thickness with cutaneous hypersensitivity associated with increased serum immunoglobulin E (IgE) levels and infiltration of inflammatory cell types including mast cells and eosinophils [1-3].

Mast cells are involved in various allergy and inflammatory responses due to the aggregation of the highaffinity IgE receptor (FceRI) on their surfaces. In recent years, there have been reports that mast cells play an important role in the induction of AD-like skin based on their production of pro-inflammatory cytokines and chemokines. An association between mast cell activation and $\mathrm{AD}$ has been suggested by the increase in mast cell number and mast cell activation in AD lesions [2]. In addition, mast cells produce inflammatory mediators such as prostaglandin $\mathrm{D}_{2}\left(\mathrm{PGD}_{2}\right)$, and induce eosinophil chemotaxis at inflammatory sites and skin inflammation in $\mathrm{AD}$ [3].

Keratinocytes have been shown to be relevant to inflammatory skin responses based on their production of pro-inflammatory chemokines. Stimulation of keratinocytes with TNF- $\alpha$ and IFN- $\gamma$ induces the expression of pro-inflammatory chemokines including thymus and activation regulated chemokine (TARC; CCL17), regulated on activation, normal T-cell expressed and secreted (RANTES; CCL5), macrophage-derived chemokine (MDC; CCL22) and interleukin 8 (IL-8; CXCL8) [4, 5].

Sanguisorbae Radix (SR) is a well-known herbal medicine that is used to treat inflammatory disease and burns in Asia. In addition, it is used to treat many types of allergic skin diseases, including urticaria, eczema, and AD. SR has been reported to exhibit anti-wrinkle, antioxidant, and anti-contact dermatitis bioactivities. However, the mechanism of action of $\mathrm{SR}$ in $\mathrm{AD}$ is poorly understood. In this study, we investigated the mechanism underlying the anti-inflammatory effects of SR water extract (WSR) using human keratinocyte ( $\mathrm{HaCaT}$ ) cells and mouse bone marrow-derived mast cells (BMMCs) to determine the best treatment method of inflammatory skin diseases such as AD.

\section{Methods}

\section{Cell culture and reagents}

BMMCs isolated from male BALB/c mice $(n=1)$ were cultured for up to 10 weeks in RPMI-1640 media containing $2 \mathrm{mM}$ L-glutamine, $0.1 \mathrm{mM}$ nonessential amino acids, antibiotics, and $10 \%$ fetal bovine serum (FBS), with $20 \%$ pokeweed mitogen-stimulated spleen condition medium (PWM-SCM) as a source of interleukin-3 (IL-3). After 3 weeks, greater than $98 \%$ of the cells were verified as BMMCs according to a previously described procedure [6].

Male BALB/c mice (5 weeks old) were purchased from Samtako BioKorea (Osan, Korea). Mice were observed every day for one week during quarantine and acclimation. All animals were maintained under standard conditions of temperature $\left(22.5 \pm 0.5{ }^{\circ} \mathrm{C}\right)$, humidity $(42.6 \pm$ $1.7 \%), 12$ h lighting (8:00 AM-8:00 PM, $290 \mathrm{~lx}$ ), ventilation (10 -15 times per hour), and diet (Teklad Global Diets, Harlan Laboratories Inc., USA). This study was conducted according to the guidelines listed in the Pharmaceutical Affairs Act of Korea Food and Drug Association (KFDA) and approved by the Animal Care and Use Committee of the Korea Institute of Oriental Medicine (KIOM, Daejeon, Korea; reference number \#14035) and performed according to the guidelines of the Animal Care and Use Committee at KIOM.

The HaCaT cell line was maintained in Dulbecco's Modified Eagle's Medium (DMEM) supplemented with $10 \%$ FBS and antibiotics $(100 \mathrm{U} / \mathrm{mL}$ penicillin and $100 \mu \mathrm{g} / \mathrm{mL}$ streptomycin) at $37{ }^{\circ} \mathrm{C}$ in a humidified $5 \%$ $\mathrm{CO}_{2}$ incubator.

The ingredients of the complete cell culture medium, FBS, and antibiotics were purchased from Lonza (Basel, Switzerland). Recombinant human TNF- $\alpha$, IFN- $\gamma$, and enzyme-linked immunosorbent assay (ELISA) kits to measure RANTES and TARC were purchased from BioLegend (San Diego, CA, USA). Cell counting kits (CCKs) for the cell cytotoxicity assay were purchased from Dojindo Molecular Technologies (Kumamoto, Japan). $\beta$-Hexosaminidase ( $p$-nitrophenyl-2-acetamido2 -deoxy- $\beta$-D-glucopyranoside; PNP-GluNAc) was purchased from Sigma-Aldrich (St. Louis, MO, USA). The primary and secondary antibodies used for Western blotting were purchased from Cell Signaling Technology (Boston, MA, USA). All other chemicals were of reagent grade. All experiments were performed at least in triplicate.

\section{Preparation of WSR}

Sanguisorbae Radix was obtained from Yeongcheon Oriental Herbal Market (Yeongcheon, Korea). All voucher specimens were deposited into the herbal bank of the KM-application center, Korea Institute of Oriental Medicine (KIOM; Daejeon, Korea) after verification by Professor Ki-Hwan Bae of the college of Pharmacy, Chungnam National University (Daejeon, Korea). To prepare the WSR, dried SR pieces $(50.0 \mathrm{~g})$ were placed in 1,000 $\mathrm{mL}$ distilled water and then extracted by $3 \mathrm{~h}$ of heating at $115{ }^{\circ} \mathrm{C}$ (Gyeongseo Extractor Cosmos-600, Inchon, Korea). Following extraction, the solution was filtered using standard testing sieves $(150 \mu \mathrm{m})$ (Retsch, Haan, Germany) and freeze-dried. The freeze-dried extract powder was dissolved in dimethyl sulfoxide 
(DMSO) and centrifuged at 14,000 rpm for $10 \mathrm{~min}$. The resulting supernatant was filtered $(0.2 \mu \mathrm{m}$ pore size $)$ and then stored at $4{ }^{\circ} \mathrm{C}$ prior to use. The acquisition was $5.3642 \mathrm{~g}$ and the yield $10.73 \%$. The powder of WSR was dissolved in $10 \%$ DMSO solution for all experiments. All experiments were performed at least in triplicate, and contain a control group as a vehicle control group containing $0.1 \%$ DMSO.

\section{Cell cytotoxicity assay}

Cell cytotoxicity was analyzed using a CCK. Cells were seeded onto 96-well plates $\left(2 \times 10^{5}\right.$ cells/well). After $24 \mathrm{~h}$, WSR was added at concentrations of 10, 50, 100, and $200 \mu \mathrm{g} / \mathrm{mL}$, and the plates were incubated for $24 \mathrm{~h}$ at $37{ }^{\circ} \mathrm{C}$ in a $5 \% \mathrm{CO}_{2}$ incubator. $\mathrm{CCK}$ solutions were added to each well and the cells incubated for $1 \mathrm{~h}$. Optical density was measured at $570 \mathrm{~nm}$ using an ELISA plate reader (Infinite M200, Tecan, Männedorf, Switzerland).

\section{$\beta$-HEX release assay}

$\beta$-Hexosaminidase $(\beta$-HEX) was quantified by spectrophotometric analysis of the hydrolysis of PNP-GluNAc. For cell stimulation, BMMCs $\left(5 \times 10^{5}\right.$ cells $\left./ \mathrm{mL}\right)$ were sensitized overnight with $100 \mathrm{ng} / \mathrm{mL}$ anti-dinitrophenyl (DNP) and then stimulated for $15 \mathrm{~min}$ with $25 \mathrm{ng} / \mathrm{mL}$ DNP-human serum albumin (HSA). To investigate the effects of WSR, varying concentrations were added $2 \mathrm{~h}$ prior to the addition of DNP-HSA. The supernatants were harvested according to a previously described procedure [7].

\section{Measurement of chemokine production}

$\mathrm{HaCaT}$ cells $\left(1 \times 10^{6}\right.$ cells/well $)$ were seeded onto 6-well plates. After $18 \mathrm{~h}$, the cells were treated with WSR at concentrations of 1,10 and $50 \mu \mathrm{g} / \mathrm{mL}$ for $2 \mathrm{~h}$ at $37^{\circ} \mathrm{C}$ in an atmosphere of $5 \% \mathrm{CO}_{2}$. After treatment, TNF- $\alpha /$ IFN- $\gamma$ (each $10 \mathrm{ng} / \mathrm{mL}$ ) was added to each well and incubated for a further $24 \mathrm{~h}$. The culture medium was then harvested and the levels of chemokines in the supernatants detected using ELISA kits according to the manufacturer's instructions.

\section{RNA isolation and real-time reverse transcription-} polymerase chain reaction (RT-PCR) analysis

Total RNA was isolated from $\mathrm{HaCaT}$ cells using the RNA-Spin total RNA extraction kit (iNtRoN, Daejeon, Korea) according to the manufacturer's instructions. Reverse transcription was carried out in a $20 \mu \mathrm{l}$ reaction with $1 \mu \mathrm{g}$ of total RNA transformed into cDNA using AccuPower CycleScript RT premix (Bioneer). For measurements of TARC, RANTES, MDC, IL- 8 and $\beta$-actin mRNA, the PCR conditions were as follows: 12 cycles of primer annealing at $25{ }^{\circ} \mathrm{C}$ for $30 \mathrm{~s}$, cDNA synthesis at $45{ }^{\circ} \mathrm{C}$ for $4 \mathrm{~min}$, melting of the secondary structure and cDNA synthesis at $55^{\circ} \mathrm{C}$ for $30 \mathrm{~s}$, and heat inactivation at $95{ }^{\circ} \mathrm{C}$ for $5 \mathrm{~min}$. The PCR-amplified primers used in this study are described in previously described [5]. Gene expression was quantified by real-time PCR using the AccuPower $2 \times$ Greenstar qPCR Master (Bioneer) according to the following protocol: pre-denaturation at $95{ }^{\circ} \mathrm{C}$ for $10 \mathrm{~min}$, followed by 40 cycles of $95{ }^{\circ} \mathrm{C}$ for $10 \mathrm{~s}$, $60{ }^{\circ} \mathrm{C}$ for $30 \mathrm{~s}$, and $72{ }^{\circ} \mathrm{C}$ for $30 \mathrm{~s}$. Amplifications were carried out using QuantStudio 6 (LifeScience, ABI, USA), The fold change in the expression of the target gene relative to the control was normalized to $\beta$-actin using the $2^{-\Delta \Delta C t}$ method.

\section{Western blotting}

Protein expression was evaluated by Western blotting according to standard procedures. The cells were pretreated with WSR and stimulated with TNF- $\alpha / \mathrm{IFN}-\gamma$ during incubation for the indicated periods at $37^{\circ} \mathrm{C}$. Cells were then harvested and resuspended in radioimmunoprecipitation assay lysis buffer (Millipore, Bedford, MA, USA) containing a protease and phosphatase inhibitor cocktail (Roche, Basel, Switzerland). After a further round of centrifugation, cell debris was discarded and the protein concentration in the supernatant was
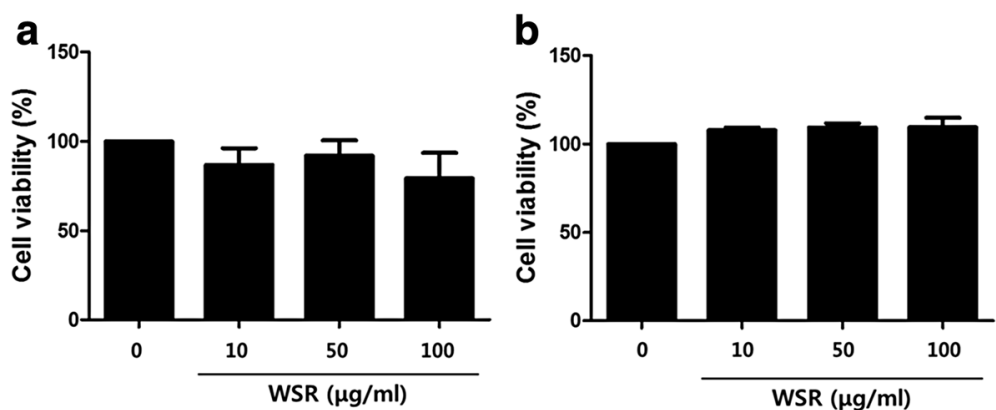

Fig. 1 Cytotoxic effects of WSR on HaCaT cells and BMMCs. Cell viability was determined using a CCK assay. Each cells were seeded into 96-well plates and treated with various concentrations of WSR for $24 \mathrm{~h}$. a Cytotoxic effects of WSR on HaCaT cells. $\mathbf{b}$ Cytotoxic effects of WSR on BMMCs. The data are presented as the means \pm SEM of three experiments 


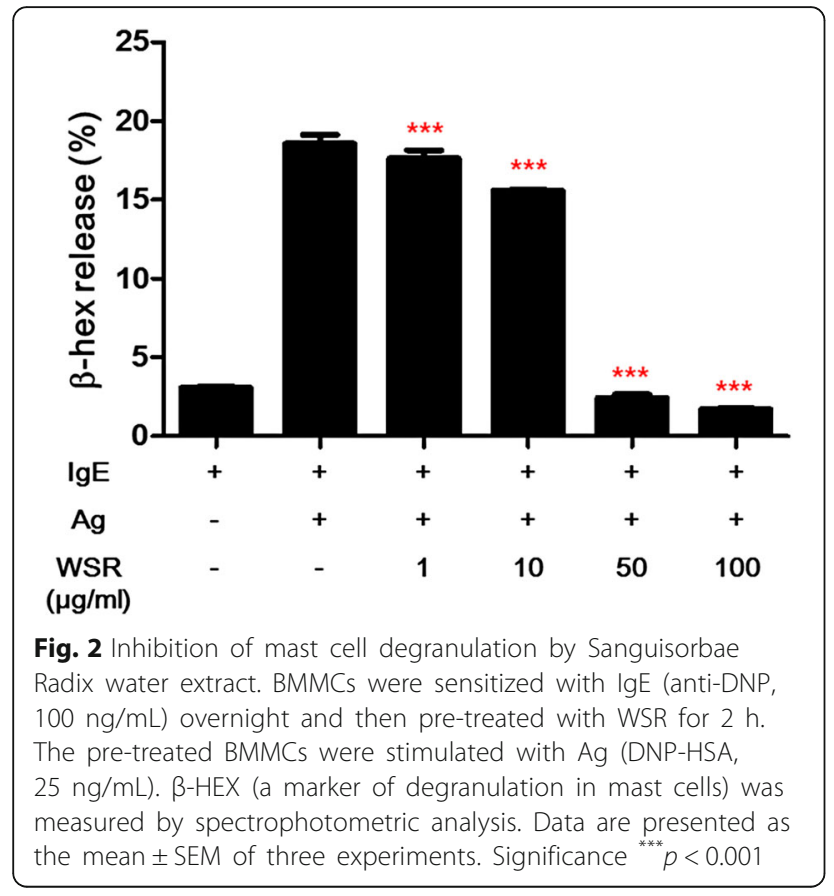

determined using Bradford's reagent. Equal amounts of protein were subjected to sodium dodecyl sulfatepolyacrylamide gel electrophoresis (SDS-PAGE). The separated proteins were transferred onto a nitrocellulose membrane (Millipore, MA, USA) followed by blocking with $3 \%$ bovine serum albumin (BSA) in Tris-buffered saline containing $0.1 \%$ Tween 20 . The membrane was incubated first with the primary antibodies at $4{ }^{\circ} \mathrm{C}$ overnight followed with horseradish-peroxidase (HRP)-conjugated secondary antibodies for $2 \mathrm{~h}$ at room temperature. Specific proteins were detected using Clarity ${ }^{\text {mit }}$ West ECL Substrate (Bio-Rad Laboratories, CA, USA).

\section{Statistical analysis}

Data were analyzed using GraphPad Prism software (ver. 5.0 GraphPad Software, San Diego, CA, USA). Results are expressed as the mean \pm standard error of the mean (SEM) and were evaluated using Student's t-test or analysis of variance (ANOVA). A $p$ value less than 0.05 was considered statistically significant.

\section{Results}

Effects of WSR on BMMC and HaCaT cell cytotoxicity

Cytotoxicity assays were performed to determine the concentration of WSR on mast cells and keratinocyte cells that would not affect cell viability. Each cell type was incubated with different concentrations of WSR (10, 50 and $100 \mu \mathrm{g} / \mathrm{mL}$ ) for $18 \mathrm{~h}$ and subjected to the CCK-8 assay. A concentration of $50 \mu \mathrm{g} / \mathrm{mL}$ WSR had no significant cytotoxic effect on either BMMCs or $\mathrm{HaCaT}$ cells over a $24 \mathrm{~h}$ period (Fig. 1). However, WSR at $100 \mu \mathrm{g} / \mathrm{mL}$ had a mild cytotoxic effect on $\mathrm{HaCaT}$ cells. Thus, we
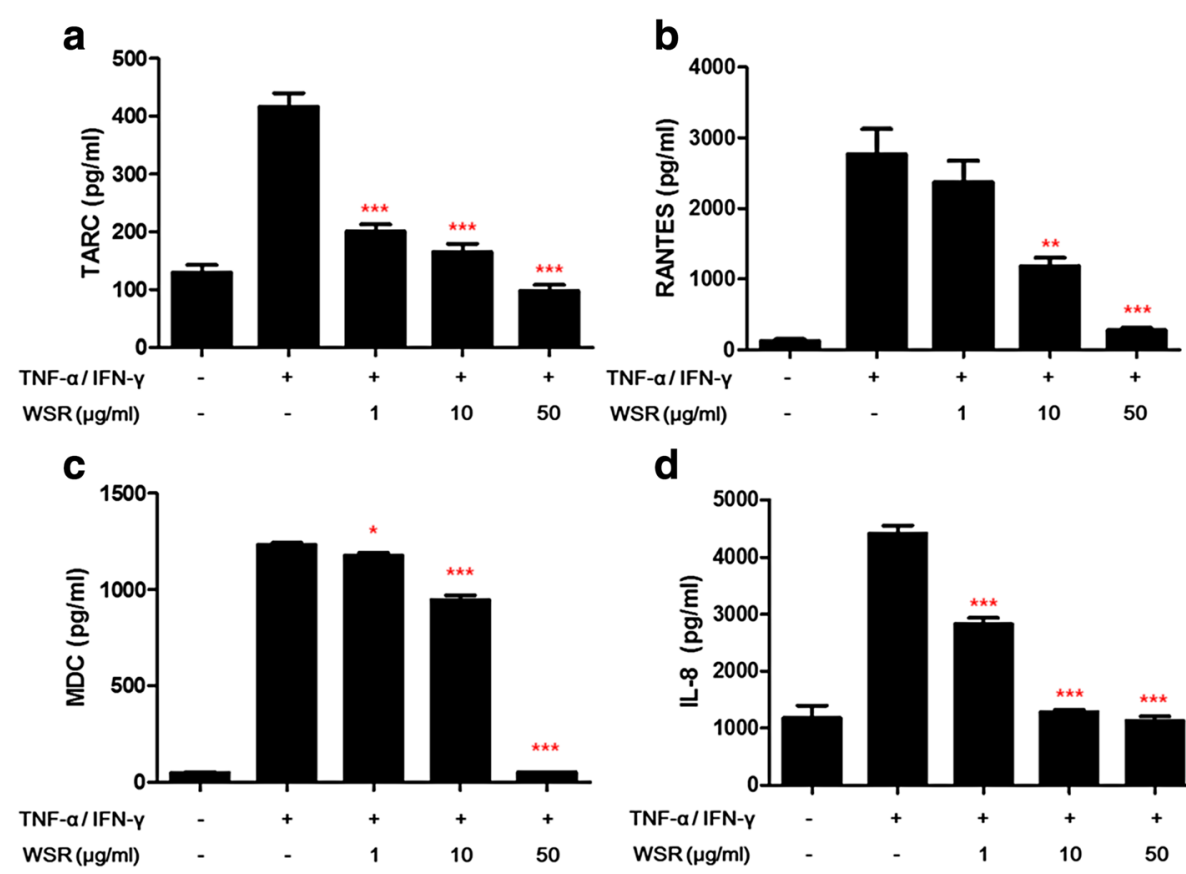

d

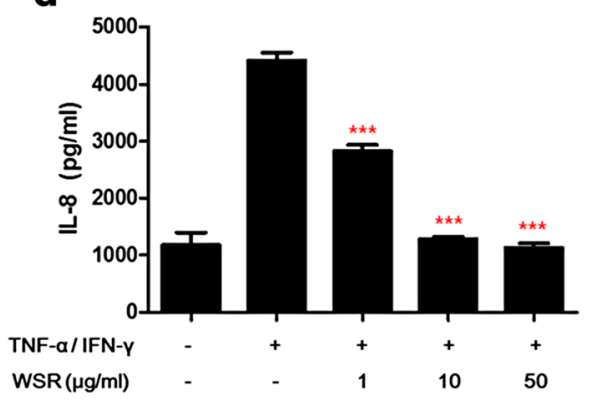

Fig. 3 Inhibitory effects of WSR on the TNF-a/IFN- - -induced production of chemokines in HaCaT cells. The production of TARC (a), RANTES (b), MDC (c), and IL-8 (d) was measured in the culture supernatant of TNF-a/IFN- $\gamma$-stimulated HaCaT cells. Cells were pre-treated with WSR for $2 \mathrm{~h}$ and then stimulated with TNF- $\mathrm{a} / \mathrm{IFN}-\gamma$ (each $10 \mathrm{ng} / \mathrm{mL}$ ) for $24 \mathrm{~h}$. Data are presented as the means \pm SEM of three experiments. Significance ${ }^{*} p<0.05$, ${ }^{* *} p<0.01,{ }^{* * *} p<0.001$ 
used WSR at concentrations of 1,10 and $50 \mu \mathrm{g} / \mathrm{mL}$ for subsequent experiments.

\section{Effects of WSR on mast cell degranulation}

Mast cells contain numerous granules and a high-affinity IgE receptor (FceRI) on their surface. Activated mast cells are degranulated and secrete various pro-inflammatory mediators in their granules such as histamine, TNF- $\alpha$, and IFN- $\gamma$ [3]. To investigate the effect of WSR on mast cell degranulation, we measured the release of $\beta$-HEX in IgE/ Ag-activated BMMCs. As a result, WSR strongly inhibited $\beta$-HEX release in a dose-dependent manner $\left(\mathrm{IC}_{50}\right.$; $27.5 \mu \mathrm{g} / \mathrm{mL}$ ) (Fig. 2).

Effects of WSR on TNF- $\alpha /$ IFN- - -induced pro-inflammatory chemokines production in $\mathrm{HaCaT}$ cells

To evaluate the anti-inflammatory activity of WSR in human keratinocytes, we measured the TNF- $\alpha / \mathrm{IFN}-\gamma$-induced production of pro-inflammatory chemokines in $\mathrm{HaCaT}$ cells. As shown in Fig. 3, TNF- $\alpha / \mathrm{IFN}-\gamma$ significantly increased the levels of chemokines TARC, RANTES, MDC and IL-8 in HaCaT cells. The results show that WSR inhibited the production of TARC,
RANTES, MDC and IL-8 in a dose-dependent manner (each $\mathrm{IC}_{50} ; 1,6,25$ and $25.4 \mu \mathrm{g} / \mathrm{mL}$, respectively).

Effects of WSR on TNF-a/IFN- $\gamma$-induced pro-inflammatory chemokines expression in $\mathrm{HaCaT}$ cells

We investigated the inhibitory effects of WSR on proinflammatory chemokine mRNA levels. The expression levels of TARC, RANTES, MDC, and IL-8 genes were determined using real-time RT-PCR. Then, as shown in Fig. 4 stimulation with TNF- $\alpha / \mathrm{IFN}-\gamma$ increased MDC, RANTES, IL-8 and TARC mRNA levels in HaCaT cells. As a result, these were significantly inhibited by WSR treatment in a concentration-dependent manner.

Effects of WSR on the activation of p38, JNK, and STAT-1/ Jak- 2 in TNF- $\alpha /$ IFN- $\boldsymbol{\gamma}$-stimulated $\mathrm{HaCaT}$ cells

Activation of JNK/ERK/p38 and STAT-1/Jak-2 are closely associated with chemokine production in TNF- $\alpha / \mathrm{IFN}-\gamma$ stimulated $\mathrm{HaCaT}$ cells [8]. Therefore, we investigated whether WSR influences TNF- $\alpha / \mathrm{IFN}-\gamma$-stimulated HaCaT cells by Western blotting. Cells were stimulated with TNF- $\alpha /$ IFN $-\gamma$ for a minimum of 5 min and a maximum of $2 \mathrm{~h}$, after which the levels of JNK/ERK/p38 and STAT-1/ Jak-2 phosphorylation were determined. The results

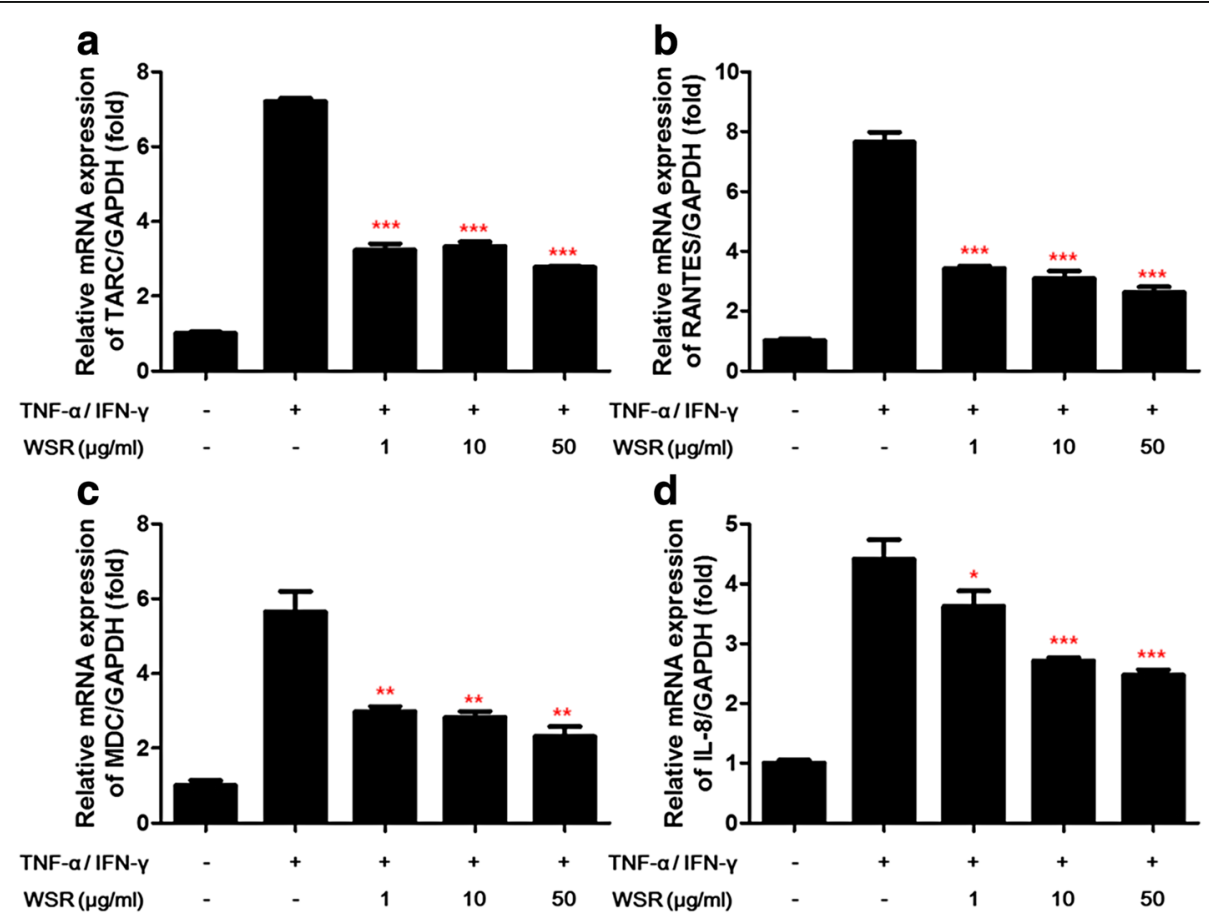

Fig. 4 Inhibitory effects of WSR on chemokine expression in TNF-a/IFN- - -stimulated HaCaT cells. Chemokines are important mediators of the immune response and inflammatory reactions. The exposure of keratinocytes to TNF-a/IFN- $\gamma$ induces the abnormal expression of chemokines, leading to the infiltration of T cells or leukocytes into inflammatory lesions in the skin [20-22]. We examined the inhibitory effects of WSR on TNF-a/IFN- $y$-induced pro-inflammatory chemokine production by HaCaT cells. We assessed the inhibitory effects of WSR on pro-inflammatory chemokine mRNA levels. The expression of TARC, RANTES, MDC, and IL-8 mRNA was then determined using real-time RT-PCR. As shown in Fig. 3, the levels of TARC, RANTES, MDC and IL-8 mRNA were enhanced in TNF-a/IFN- $\gamma$-stimulated cells. These increases were dose-dependently inhibited following WSR treatment. Data are presented as the means \pm SEM of three experiments. Significance ${ }^{*} p<0.05,{ }^{* *} p<0.01,{ }^{* *} p<0.001$ 

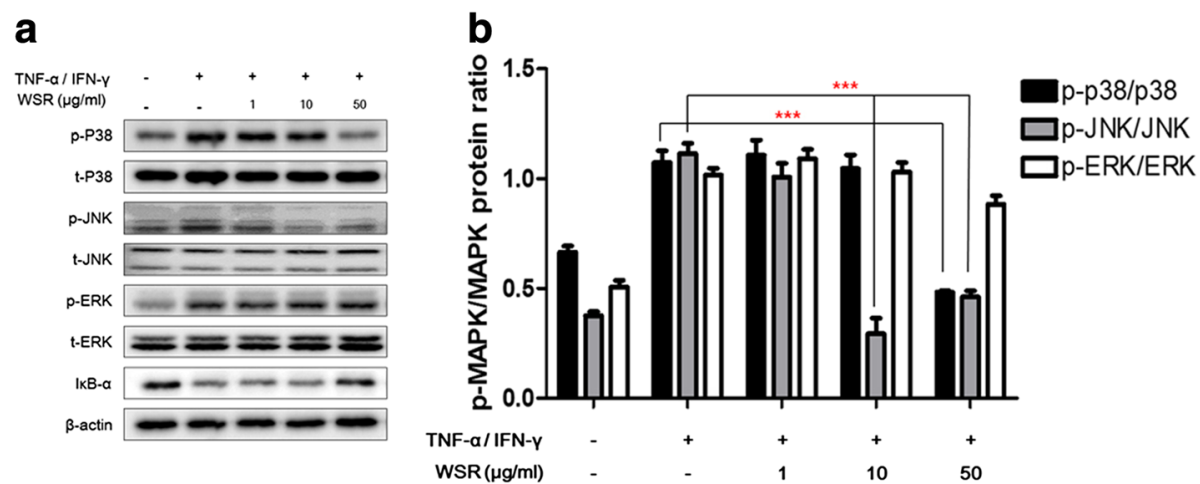

Fig. 5 Inhibitory effects of WSR on MAPK phosphorylation in TNF-a/IFN-y-stimulated HaCaT cells. HaCaT cells were pre-treated with the indicated concentrations of WSR for $2 \mathrm{~h}$ and then stimulated with TNF-a/FN- $\gamma$ (each $10 \mathrm{ng} / \mathrm{mL}$ ) for $30 \mathrm{~min}$. The expression or phosphorylation of the indicated proteins was determined in whole-cell lysates by Western blotting using the indicated antibodies. Data are presented as the means \pm SEM of three experiments. Significance ${ }^{* *} p<0.001$

showed the effects of $50 \mu \mathrm{g} / \mathrm{mL}$ WSR on p38 and JNK activities (Fig. 5). In addition, WSR strongly inhibited the activity of STAT-1 by approximately $53 \%$ at a concentration of $10 \mu \mathrm{g} / \mathrm{mL}$, and suppressed the activity of Jak-2 by approximately $81 \%$ at a concentration of $50 \mu \mathrm{g} / \mathrm{mL}$ without affecting the total protein level (Fig. 6).

\section{Discussion}

Many studies have reported that high levels of $\mathrm{IgE}$ are observed in the serum of AD patients. An increased IgE level in the serum induces the activation of mast cells, which causes an allergic reaction. IgE secretion is an important characteristic of $\mathrm{AD}$, with elevated levels related to disease severity in $\mathrm{AD}$ patients $[2,3]$. In addition, an association between mast cell activation and $\mathrm{AD}$ is suggested by the increase in mast cell counts and activation in AD lesions [9]. IgE binds with a high-affinity receptor for IgE (FceRI) expressed on the mast cell surface. There are numerous uncertain factors that affect the antigens in $\mathrm{AD}$. The IgE/antigen-bound FceRI on mast cells leads

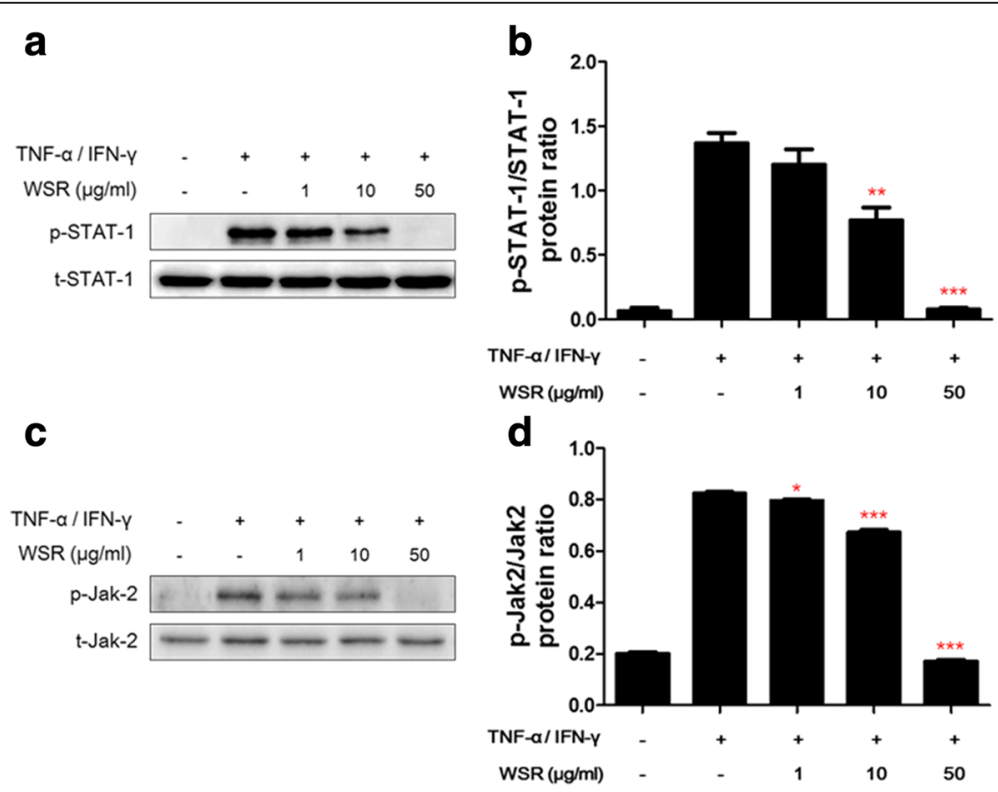

Fig. 6 Inhibitory effects of WSR on STAT-1 and Jak-2 phosphorylation in TNF-a/IFN- - -stimulated HaCaT cells. HaCaT cells were pre-treated with the indicated concentrations of WSR for $2 \mathrm{~h}$ and then stimulated with TNF-a/IFN- $\gamma$ (each $10 \mathrm{ng} / \mathrm{mL}$ ) for $30 \mathrm{~min}$. a The phosphorylation or protein level in whole-cell lysates was determined by Western blotting using antibodies against phospho-STAT-1, STAT, and the band density of p-STAT1/STA-1. b The phosphorylation or level of each protein in whole-cell lysates was determined by Western blotting using antibodies against phosphor-Jak-2, Jak-2, and the band density of $\mathrm{p}$-Jak-2/Jak-2. Data are presented as the means \pm SEM of three experiments. Significance ${ }^{*} p<0.05$, ${ }^{* *} p<0.01,{ }^{* * *} p<0.001$. The English in this document has been checked by at least two professional editors, both native speakers of English. For a certificate, please see: http://www.textcheck.com/certificate/6AbvJG 
to cell activation. The activated mast cells degranulate and secrete various pro-inflammatory mediators in their granules such as histamine, TNF- $\alpha$, and IFN- $\gamma[3,4,10]$. After the degranulation process, fever and itching is induced in skin lesions by inflammatory mediators that are released from mast cells. Severe itching and the consequential scratching behaviors are factors that deepen in $\mathrm{AD}$.

Keratinocytes play an important role in inflammatory skin disease by producing pro-inflammatory chemokines. Many studies have reported that TNF- $\alpha /$ IFN- $\gamma$ treatment increases the production of chemokines in $\mathrm{HaCaT}$ cells. TNF- $\alpha / \mathrm{IFN}-\gamma$-stimulation activates several intracellular signaling pathways, including mitogen-activated protein kinases (MAPKs) and STAT-1/Jak-2 [11] [9]. MAPKs and STAT/Jak signaling pathways have been shown to be involved in the regulation of chemokine production in $\mathrm{HaCaT}$ cells. These cascades play an important role in immune responses and regulate the inflammatory signaling pathway $[9,12]$.

Sanguisorbae Radix has been reported that it possesses some beneficial effects such as anti-cancer [13], antiinflammation [5, 14], anti-oxidation [15], neuroprotection [16, 17] and renal protection [18]. Currently, we have reported the inhibitory action of its ethanol extract on 2, 4-dinitrochlorobenzene (DNCB)-induced $\mathrm{AD}$ model [19]. Nonetheless, the inhibitory mechanism of Sanguisorbae Radix in AD responses is still unclarified. Therefore, in present study, we establish how aqueous extract of Sanguisorbae Radix possesses the inhibitory actions against $\mathrm{AD}$ responses in both $\mathrm{IgE} / \mathrm{Ag}$-activated mast cells and TNF- $\alpha / \mathrm{IFN}-\gamma$-stimulated keratinocytes.

In present data, when IgE-sensitized BMMCs were preincubated with WSR prior to antigen challenge, WSR dose-dependently inhibited degranulation of the above cells. It suggests that WSR has anti-allergic action by inhibiting degranulation of IgE/Ag-activated mast cells. In addition, regulating activation of TNF- $\alpha /$ IFN- $\gamma$-stimulated keratinocytes is another important factor for prevention and treatment of $A D$. In this study, WSR not only inhibited formation of chemokines such as TARC, RANTES, MDC and IL-8, but also suppressed the activation of $\mathrm{p} 38$ and JNK as well as STAT-1/Jak-2 pathway in TNF- $\alpha / \mathrm{IFN}-\gamma$-stimulated $\mathrm{HaCaT}$ cells. It indicates that WSR exerts anti-inflammatory action by suppressing chemokine production in TNF- $\alpha / \mathrm{IFN}-\gamma$-stimulated keratinocytes.

\section{Conclusions}

This results demonstrate that WSR inhibits degranulation of IgE/Ag-activated mast cells and inhibits the production of pro-inflammatory chemokines by suppressing the phosphorylation of p38 and JNK in HaCaT cells.

\section{Acknowledgements}

This work was supported by the grant K16281 awarded to Korea Institute of Oriental Medicine (KIOM) from the Ministry of Education, Science and Technology (MEST), Korea.

\section{Funding}

This work was supported by the grant K16281 awarded to Korea Institute of Oriental Medicine (KIOM) from the Ministry of Education, Science and Technology (MEST), Korea.

\section{Availability of data and materials}

The datasets supporting the conclusions of this article are included within the article.

\section{Authors' contributions}

$J H Y$ and WKC designed the study, performed the research, and prepared the manuscript; JMY was involved in the experiments; JYM supervised the study. All authors read and approved the final manuscript.

\section{Competing interests}

The authors declare that they have no competing interest.

Consent for publication

Not applicable.

\section{Ethics approval and consent to participate}

All animal experiments were approved by the Animal Care and Use Committee of the Korea Institute of Oriental Medicine (KIOM, Daejeon, Korea; reference number \#14-035) and performed according to the guidelines of the Animal Care and Use Committee at KIOM.

Received: 22 June 2016 Accepted: 24 August 2016

Published online: 06 September 2016

\section{References}

1. Karuppagounder V, Arumugam S, Thandavarayan RA, Pitchaimani V, Sreedhar R, Afrin R, Harima M, Suzuki H, Nomoto M, Miyashita S, et al. Tannic acid modulates NFkappaB signaling pathway and skin inflammation in NC/Nga mice through PPARgamma expression. Cytokine. 2015;76(2):206-13.

2. Liu FT, Goodarzi H, Chen HY. IgE, mast cells, and eosinophils in atopic dermatitis. Clin Rev Allergy Immunol. 2011;41(3):298-310.

3. Kawakami T, Ando T, Kimura M, Wilson BS, Kawakami Y. Mast cells in atopic dermatitis. Curr Opin Immunol. 2009:21(6):666-78.

4. Nedoszytko B, Sokolowska-Wojdylo M, Ruckemann-Dziurdzinska K, Roszkiewicz J, Nowicki RJ. Chemokines and cytokines network in the pathogenesis of the inflammatory skin diseases: atopic dermatitis, psoriasis and skin mastocytosis. Postepy Dermatol Alergol. 2014;31(2):84-91.

5. Ju-Hye Yang Y-HH, Min-Jung G, Won-Kyung C, Jin Yeul M. Ethanol extracts of Sanguisorba officinalis L. suppress TNF-a/IFN- $\gamma$-induced proinflammatory chemokine production in $\mathrm{HaCaT}$ cells. Phytomedicine. 2015; 22:1262.

6. Lu Y, Yang JH, Li X, Hwangbo K, Hwang SL, Taketomi Y, Murakami M, Chang YC, Kim CH, Son JK, et al. Emodin, a naturally occurring anthraquinone derivative, suppresses lgE-mediated anaphylactic reaction and mast cell activation. Biochem Pharmacol. 2011;82(11):1700-8.

7. Lu Y, Li Y, Jin M, Yang JH, Li X, Chao GH, Park HH, Park YN, Son JK, Lee E, et al. Inula japonica extract inhibits mast cell-mediated allergic reaction and mast cell activation. J Ethnopharmacol. 2012;143(1):151-7.

8. Jeong SJ, Lim HS, Seo CS, Kim JH, Jin SE, Yoo SR, Shin HK. Traditional herbal formula Jakyakgamcho-tang (Paeonia lactiflora and Glycyrrhiza uralensis) impairs inflammatory chemokine production by inhibiting activation of STAT1 and NF-kappaB in HaCaT cells. Phytomedicine. 2015;22(2):326-32.

9. Choi JK, Kim SH. Inhibitory effect of galangin on atopic dermatitis-like skin lesions. Food Chem Toxicol. 2014;68:135-41.

10. Brandt EB, Sivaprasad U. Th2 Cytokines and Atopic Dermatitis. J Clin Cell Immunol. 2011;2(3):110.

11. Qi XF, Kim DH, Yoon YS, Li JH, Song SB, Jin D, Huang XZ, Teng YC, Lee KJ. The adenylyl cyclase-cAMP system suppresses TARC/CCL17 and MDC/CCL22 production through p38 MAPK and NF-kappaB in HaCaT keratinocytes. Mol Immunol. 2009;46(10):1925-34. 
12. Sung YY, Kim YS, Kim HK. Illicium verum extract inhibits TNF-alpha- and IFNgamma-induced expression of chemokines and cytokines in human keratinocytes. J Ethnopharmacol. 2012;144(1):182-9.

13. Cai Z, Li W, Wang H, Yan W, Zhou Y, Wang G, Cui J, Wang F. Anti-tumor and immunomodulating activities of a polysaccharide from the root of Sanquisorba officinalis L. Int J Biol Macromol. 2012;51(4):484-8.

14. Jo S, Ryu J, Kim H, Kim M, Ryu MH, Kim H, Cho Sl. Anti-inflammatory effects of Sanguisorbae Radix on contact dermatitis induced by dinitrofluorobenzene in mice. Chin J Integr Med. 2015. doi:10.1007/s11655015-2148-8.

15. Zhang L, Koyyalamudi SR, Jeong SC, Reddy N, Smith PT, Ananthan R, Longvah T. Antioxidant and immunomodulatory activities of polysaccharides from the roots of Sanguisorba officinalis. Int J Biol Macromol. 2012;51(5):1057-62.

16. Ban JY, Nguyen HT, Lee HJ, Cho SO, Ju HS, Kim JY, Bae K, Song KS, Seong $\mathrm{YH}$. Neuroprotective properties of gallic acid from Sanguisorbae radix on amyloid beta protein (25-35)-induced toxicity in cultured rat cortical neurons. Biol Pharm Bull. 2008;31(1):149-53.

17. Nguyen TT, Cho SO, Ban JY, Kim JY, Ju HS, Koh SB, Song KS, Seong YH. Neuroprotective effect of Sanguisorbae radix against oxidative stressinduced brain damage: in vitro and in vivo. Biol Pharm Bull. 2008;31(11): 2028-35.

18. Chen CP, Yokozawa T, Kitani K. Beneficial effects of sanguisorbae radix in renal dysfunction caused by endotoxin in vivo. Biol Pharm Bull. 1999;22(12): 1327-30.

19. Yang JH, Yoo JM, Cho WK, Ma JY. Ethanol extract of sanguisorbae radix inhibits mast cell degranulation and suppresses 2,4-dinitrochlorobenzeneinduced atopic dermatitis-like skin lesions. Mediators Inflamm. 2016;2016: 2947390.

20. Choi JH, Jin SW, Park BH, Kim HG, Khanal T, Han HJ, Hwang YP, Choi JM, Chung YC, Hwang SK, et al. Cultivated ginseng inhibits 2,4dinitrochlorobenzene-induced atopic dermatitis-like skin lesions in NC/Nga mice and TNF-alpha/IFN-gamma-induced TARC activation in $\mathrm{HaCaT}$ cells. Food Chem Toxicol. 2013;56:195-203.

21. Kwon DJ, Bae YS, Ju SM, Goh AR, Youn GS, Choi SY, Park J. Casuarinin suppresses TARC/CCL17 and MDC/CCL22 production via blockade of NFkappaB and STAT1 activation in HaCaT cells. Biochem Biophys Res Commun. 2012;417(4):1254-9.

22. Jung MR, Lee $T H$, Bang MH, Kim H, Son Y, Chung DK, Kim J. Suppression of thymus- and activation-regulated chemokine (TARC/CCL17) production by 3-O-beta-D-glucopyanosylspinasterol via blocking NF-kappaB and STAT1 signaling pathways in TNF-alpha and IFN-gamma-induced $\mathrm{HaCaT}$ keratinocytes. Biochem Biophys Res Commun. 2012;427(2):236-41.

\section{Submit your next manuscript to BioMed Central and we will help you at every step:}

- We accept pre-submission inquiries

- Our selector tool helps you to find the most relevant journal

- We provide round the clock customer support

- Convenient online submission

- Thorough peer review

- Inclusion in PubMed and all major indexing services

- Maximum visibility for your research

Submit your manuscript at www.biomedcentral.com/submit

CBiomed Central 